\title{
Energy access in informal settlements to achieve the Sustainable Development Goals
}

Francesco Fuso Nerini ( $\nabla$ francesco.fusonerini@energy.kth.se )

Royal Institute of Technology https://orcid.org/0000-0002-4770-4051

Emily Christley

KTH - Royal Institute of Technology

Hanna Ljungberg

$\mathrm{KTH}$ - Royal Institute of Technology

\section{Emmanuel Ackom}

Technical University of Denmark https://orcid.org/0000-0002-9006-3501

\section{Analysis}

Keywords: energy access, SDG

Posted Date: March 23rd, 2021

DOl: https://doi.org/10.21203/rs.3.rs-102995/v1

License: (c) (i) This work is licensed under a Creative Commons Attribution 4.0 International License. Read Full License 


\section{Abstract}

Over one billion people live in urban dwellers without adequate access to basic services such as energy, water, and healthcare. Here we use the SDG 'lens' to evaluate how local policies and plans for energy access in informal settlements can be coordinated with the SDGs achievement. With a case study in Kibera, Kenya, we analyse how local energy access could enable or inhibit all local SDG Targets. Then, based on this knowledge, we propose a set of actions to achieve full modern energy access without compromising other local Sustainable Development Goals. Furthermore, we propose a new taxonomy to evaluate how actions affect the interlinkages between local energy access and the achievement of the SDGs.

\section{Introduction}

Today, an estimated fifty five percent (55\%) of the world's population, representing 4.3 billion people, live in urban spaces. By 2050 , this number is predicted to reach seventy percent $(70 \%)^{1}$. Globally, approximately 1 in 3 urban inhabitants dwell in informal settlements and slum households, without access to basic services - potable water, appropriate housing, healthcare - and modern energy ${ }^{1,2}$. In sub-Saharan Africa more than fifty percent (50\%) of urban households live in such conditions with some countries reporting numbers as high as ninety percent $(90 \%)^{3}$ (Figure 1 ). Broto et al. ${ }^{4}$ highlighted the need for the inclusion of these urban slums and informal settlements in the energy access agenda.

Energy is an enabler for sustainable development. However, with growing urbanisation across the developing world - a result of internal population growth and rural-urban migration - the inaccessibility of modern energy services to these urban communities presents an urgent challenge ${ }^{5}$. Earlier studies have examined energy access in urban areas from the perspectives of energy poverty measurements ${ }^{6}$; barriers and enabling frameworks ${ }^{5}$; energy justice, sustainability assessments and transitions ${ }^{7-9}$; health $^{10-12}$; and political economy ${ }^{13}$. To date, no study has investigated energy access in slums and informal settlements from the context of achieving the United Nations 2030 Agenda.

The United Nations 2030 Agenda's 17 Sustainable Development Goals, or SDGs, capture global aspirations: from the eradication of poverty to the strengthening on worldwide partnerships ${ }^{14}$. These Global Goals are increasingly being adopted as a lens with which to analyse and understand such complex challenges and intersectoral implications of projects and policies across a variety of sectors (e.g. ${ }^{15-19}$ ). Moreover, the SDG 'lens' can be used as a decision-making tool to prioritise effective actions for reaching a policy objective $\mathrm{e}^{20}$. In this Analysis, we apply this lens to analyse how energy access in slums and informal settlements relate to the achievement of the SDGs. To the best of our knowledge, this is the first time that the SDGs have been applied to this challenge.

We draw on a case study of Kibera located in Nairobi, Kenya (Figure 2). Fifty-six percent (56\%) of urban inhabitants dwell in slum households in the country ${ }^{2}$, and Kibera is believed to be the "largest slum in Africa"22. 
With an estimated population between 200,000 and 700,000 people, Kibera occupies a land area of approximatley two square-kilometers ${ }^{22,23}$. As the land it occupies is formally considered government property, Kibera is classified as an informal settlement and thus residents are considered to be squatters, associated with insecurity of tenancy and high vulnerability ${ }^{24-26}$. Energy access challenges in the neighbourhood are considerable, with barriers of high supplier and consumer cost, unreliability of supply, lack of awareness, safety concerns, and a lack of leadership ${ }^{27}$. In our study we narrow our focus to two energy options, electricity and cooking using liquified petroleum gas (LPG), each considered to be modern and cleaner energy options ${ }^{28}$. LPG is currently being utilised within the country using established and documented supply chains but not at scale, despite its active promotion by the Kenyan Government ${ }^{29,30}$.

By applying the SDG lens to the challenge of energy access in slums and informal settlements, we assess its importance to the achievement of the 2030 Agenda. We examine how energy access in slums and informal settlements relates to the achievement of each SDG Target, applying that knowledge to the chosen case study. Knowing how energy access can enable or inhibit SDG Targets, we take our Analysis further: applying actions to promote energy access to each mapped Target to investigate how these actions can be designed and refined to support the achievement of all SDGs. Our developed methodology (see Methods) can inform policymakers as to the cross-sectoral impact of actions, helping in their design, improvement, and ultimate achievement of the SDGs.

\section{Using the SDG lens to map the impact of energy access in Kibera}

We assessed the importance of energy access to the achievement of SDG Targets in Kibera. Figure 3 presents the outcome of mapping, illustrating where access to electricity and LPG enables or inhibits the achievement of each SDG Target locally.

Figure 3Detailed assessment of the provision of electricity and LPG access on the SDGs. Evidence of interlinkage that promoted either energy access or Target was marked as an enabler, whilst those that prohibited energy access or Target were marked as an inhibitor from SDGs. In the absence of evidence, no interlinkages were marked, meaning only the absence of published evidence, not necessarily absence of impact. Full results can be found in Supplementary Material.

Targets across SDGs 1, 3, 4, 5, 8, 10, 11, 16 are enabled by access to modern and clean energy, alleviating poverty and improving living conditions ${ }^{31}$, benefiting Targets such as 1.1: By 2030, eradicate extreme poverty for all people everywhere and 11.1: By 2030, ensure access for all to adequate, safe and affordable housing and basic services and upgrade slums ${ }^{32}$.

Enabling Targets of SDGs 8 and 10, energy access provides an opportunity for productive employment and growth of home-based small- and medium-sized Enterprises (SMEs) ${ }^{33}$. For example, small-scale, homebased food vendors in Kibera using charcoal and kerosene fuels for cooking could, with the appropriate enabling conditions, transition to $\mathrm{LPG}^{34}$. As a cleaner fuel option, LPG has the added benefits of allowing for faster service, cost savings and increased earnings ${ }^{33,34}$. Similarly, electricity can power shops and 
restaurants, providing refrigeration for food storage and extending shelf-life, allowing for longer working hours with improved lighting, and improving customer service ${ }^{33}$.

However, a common barrier to energy access in slums and informal settlement is its high upfront cost for consumers $^{27}$. For residents in Kibera where the average household income is $118,216 \mathrm{KSh} /$ year $(1090$

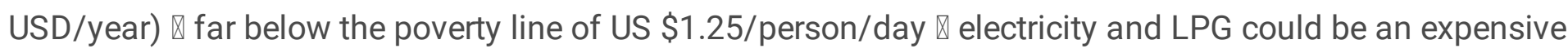
alternative to charcoal and kerosene which is typically purchased in small quantities on a day-to-day basis $^{35,36}$. Increased daily costs could inhibit their ability to pay for other basic services ${ }^{27}$. This inhibits Targets such as 2.1: By 2030, end hunger and ensure access by all people, 6.1: By 2030, achieve universal and equitable access to safe and affordable drinking water for all, and 7.1: By 2030, ensure universal access to affordable, reliable and modern energy services which specifically mentions the need for "affordable" energy access $^{32}$.

\section{An action plan to promote energy access in informal settlements whilst achieving SDG Targets}

Having mapped the impact of electricity and LPG access on the achievement of the SDGs in Kibera, we take our Analysis further, applying the knowledge to possible actions to promote energy access (Table 1). As described in Methods, proposed actions seek to provide energy access in informal settlements while reinforcing identified enablers and removing - to the extent possible - inhibitors with the SDGs Targets.

Table 1. Actions to overcome key barriers for energy. Proposed actions aim to overcome identified barriers to electricity and LPG access whilst complementing their respective supply chains and existing policies, projects, and programmes in place in Kenya.

\begin{tabular}{|lll|}
\hline BARRIER TO ENERGY ACCESS & $\begin{array}{l}\text { ACTIONS TO } \\
\text { PROMOTE } \\
\text { ENERGY } \\
\text { ACCESS }\end{array}$ & EXAMPLE \\
\hline $\begin{array}{l}\text { Lack of affordability due to high } \\
\text { upfront cost of electricity and }\end{array}$ & $\begin{array}{l}\text { Financial } \\
\text { incentives }\end{array}$ & $\begin{array}{l}\text { Subsidies, payment of energy services provided } \\
\text { (rather than the cost of energy infrastructure), } \\
\text { prepayment methods, lifeline tariffs }\end{array}$ \\
$\begin{array}{l}\text { Reliability of supply leading to } \\
\text { electricity and fuel shortages }\end{array}$ & $\begin{array}{l}\text { Strengthening } \\
\text { supply chains }\end{array}$ & Network expansion, Standardisation, Outlets \\
$\begin{array}{l}\text { Lack of awareness for the } \\
\text { benefits of modern and clean } \\
\text { energy access and actions in } \\
\text { place to support its promotion }\end{array}$ & $\begin{array}{l}\text { Community } \\
\text { engagement }\end{array}$ & $\begin{array}{l}\text { Awareness programmes, community } \\
\text { participation }\end{array}$ \\
\hline $\begin{array}{l}\text { Political ambivalence for the } \\
\text { energy needs for slums and } \\
\text { informal settlements }\end{array}$ & $\begin{array}{l}\text { Political buy- } \\
\text { in, } \\
\text { recognition, } \\
\text { and/or } \\
\text { ownership }\end{array}$ & $\begin{array}{l}\text { Public awareness, mainstreaming Sustainable } \\
\text { Energy for All and SDG 7 at the various levels of } \\
\text { governments at national and sub-national }\end{array}$ \\
\hline & regional, municipal, district) level \\
\hline
\end{tabular}

The impact of actions to promote energy access in Kibera are illustrated in Figure 4: from creating new enablers, strengthening those in existence, to limiting or overcoming inhibitors (see Methods for a full 
description of classification). Impacts can be seen across all 17 Goals with varying effects on Targets.

Figure 4 Detailed assessment of the impact of interventions to promote electricity (top) and LPG (bottom) access on the SDGs. Evidence of impact of interventions on Target was classified as follows: i) New enabler (achievement of Target created by intervention); ii) Strengthened enabler (achievement of Target improved by interventions); iii) Limited inhibitor (barrier(s) to achievement of Target lessened by intervention); iv) Overcame inhibitor (barrier(s) to achievement of Target removed by intervention). In the absence of evidence, no impacts of interventions were marked, meaning only the absence of published evidence, not necessarily absence of impact.

Compared to previous mapping (Figure 3) actions to promote electricity access strengthen 62 enablers, create a further 7 enablers, overcome 17 inhibitors and limit 11. Actions to promote LPG access strengthened 52 enablers and created a further 11, overcoming 17 inhibitors and limiting 7 . Full results can be found in Supplementary Material.

Financial incentives overcame the inhibitors of affordability for Targets 2.1, 6.1, 11.1, previously discussed, as well as reducing the household burden on women and creating opportunities for income-generating activities, strengthening enablers of SDGs 5 and $8^{37}$. However, whilst subsidies, lifeline tariffs and prepayment methods are widely adopted policy tools to lower fuel and electricity costs, they must be properly designed in order to benefit their intended recipients ${ }^{38}$. For some Targets (e.g. 1.3: Implement nationally appropriate social protection systems and measures for all ${ }^{32}$ ) financial innovations only limit inhibitors.

Strengthening the supply chains of LPG improves not only its availability, but also safety, affordability, and environmental sustainability ${ }^{39}$. Investments in bulk storage will improve the affordability of LPG, allowing economies of scale in imports as the port of Mombasa can handle large volumes of LPG imports, and improving security of supply concerns as Kenya has buffer stocks that can be drawn upon in times of shortage or high prices ${ }^{40}$. This impacts those Targets whose indicators refer to the Sendai Framework for Disaster Risk Reduction $(1.5,11 . b, 13.1)^{32}$, creating enablers and limiting inhibitors; although the country's reliance of import ultimately limits the energy sovereignty of Kenya, so inhibitors relating to imports will never be entirely overcome ${ }^{41}$.

Engaging the local community will have a widespread impact on the achievement of the SDGs ${ }^{27}$. Programmes to raise public awareness can highlight the benefits of electricity and LPG and educate users on the safe use and storage of cylinders. Such programmes can also be used as a platform for education, strengthening enablers for Targets of education and training (SDGs 3, 4 and 5). Community engagement involves the inclusion of residents in informal settlements. Involvement of women's groups in community discussions in the delivery of energy strengthens enablers of socially focussed SDGs and Targets, such as 5.5: Ensure women's full and effective participation and equal opportunities for leadership and 10.2: By 2030, empower and promote the social, economic and political inclusion of all $32,37,42$.

Political buy-in and recognition acknowledges the energy needs and practices of households in Kibera to overcome several inhibitors, ensuring actions to promote energy access reach those in need e.g. Target 1.3: By 2030 , ensure that all men and women, in particular the poor and the vulnerable, have equal rights ${ }^{32}$. By 
acknowledging Kibera's residents as active leaders, communities can be mobilised and empowered if supported by government strategies of growth, education, and vocational training thus strengthening enablers to SDGs $4,5,11,16$.

\section{Lessons learnt for energy access in informal settlements}

By analysing how energy access in slums and informal settlements relates to the local achievement of all SDG Targets, we reveal the intersectoral implications of actions beyond energy, included co-benefits for health, water and sanitation, climate, and other SDGs. Our methodology, applying a new taxonomy that classifies the impact of actions to promote energy access, highlights which Targets could be more easily achieved through interventions in the energy system and those that are beyond reach. For policymakers in developing countries with limited resources, such SDG mapping allows for effective prioritising by revealing the Targets most accessible.

The 'SDG lens', as applied here, can be a powerful tool for the evaluation of actions. By capturing the crosssectoral implications of energy decision, policies, and projects (that can be seen as a combination of actions) can be designed or refined to increase their impact of promoting energy access and achieving the SDGs. Through the 17 Global Goals, the lens encompasses the economic, social, technical, legal, and environmental perspectives that must be considered when tackling complex challenges. Nowhere is this more important than in slums and informal settlements that, with multiple deprivations, need coherent and coordinated action to achieve the 2030 Agenda. Following our demonstrated methodology, the SDG lens could be applied in other contexts, be it in other informal settlements, or to other challenges, such as the provision of water or sanitation. Applied as a framework to direct national policies and strategic projects, the SDG lens offers a holistic outlook, helping to unpack discrete thinking and support integrated sustainable future for all.

\section{Methods}

To apply the SDG lens to the challenge of providing energy access in informal settlements, we developed an iterative two-step approach for SDG mapping as illustrated in Figure 5.

\section{Step 1}

We adapted the methodology of Fuso Nerini et al. $2018^{16}$ that assessed interlinkages between energy system and the 2030 Agenda and categorized them in terms of synergies and trade-offs. Through a search of published studies and grey literature, Fuso Nerini et al. $2018^{16}$ identified evidence of interactions between the achievement of each Target and the pursuit of SDG 7; the synergies and trade-offs of the interactions were then characterised using a consensus-based expert elicitation process. Using a similar systematic mapping of available literature, we sought to answer the question "Will the provision of electricity or LPG access in Kibera enable or inhibit the achievement of the Target, or vice versa?". Evidence of an interlinkage that promoted either energy access or Target was marked as an enabler, whilst those that prohibited energy access or Target were marked as an inhibitor. In the absence of evidence, no interlinkages were marked, meaning the absence of published evidence, rather than the absence of an interlinkage. 


\section{Step 2}

In the second step, we selected a set of actions to overcome common barriers and promote energy access in informal settlements. Common barriers were identified from literature focussing on energy access challenges in slums and informal settlements across the Global South ${ }^{43-45}$. Actions to overcome barriers were based on known interventions and best practices for implementing basic services into slums and informal settlements around the world and applicable to existing policies, projects, and programmes in place in Kibera, and Kenya, today $43,44,46,47$. We then evaluated each SDG Target once again, asking "How will actions to promote electricity and LPG access impact the achievement of the Target?". In answer, we developed a classifications system to allow for systematic thinking beyond simply enablers and inhibitors ${ }^{48}$. The taxonomy was based on the outcome of previous mapping (Step 1), i.e. a Target identified to be enabled by electricity and/or LPG access could be further strengthened through actions to further promote access (see examples in Table 2).

\section{Table 2 Taxonomy to evaluate how actions affect interlinkage between actions to promote energy access and the SDG Targets}

\begin{tabular}{|c|c|c|}
\hline CLASSIFICATION & EXPLANATION & EXAMPLE \\
\hline Create Enabler & $\begin{array}{l}\text { Enabler, not previously } \\
\text { identified, created as a result } \\
\text { of actions. }\end{array}$ & $\begin{array}{l}\text { Political recognition means consideration and } \\
\text { recognition of informal settlements in national } \\
\text { policy and decision-making. }\end{array}$ \\
\hline $\begin{array}{l}\text { Strengthen } \\
\text { Enabler }\end{array}$ & $\begin{array}{l}\text { Enabler previously identified } \\
\text { improved as a result of } \\
\text { actions. }\end{array}$ & $\begin{array}{l}\text { Programmes to raise awareness in the safe use of } \\
\text { energy can be used as an educative platform. }\end{array}$ \\
\hline $\begin{array}{l}\text { Overcome } \\
\text { Inhibitor }\end{array}$ & $\begin{array}{l}\text { Inhibitor previously identified } \\
\text { removed as a result of } \\
\text { actions. }\end{array}$ & $\begin{array}{l}\text { Financial incentives improve the affordability of } \\
\text { energy for households. }\end{array}$ \\
\hline Limit Inhibitor & $\begin{array}{l}\text { Inhibitor previously identified } \\
\text { lessened, but not eliminated, } \\
\text { as a result of actions. }\end{array}$ & $\begin{array}{l}\text { Strengthening supply chain improve security of } \\
\text { LPG supply but does not influence the global oil } \\
\text { price and Kenya remains dependent on imports. }\end{array}$ \\
\hline $\begin{array}{l}\text { Interlinkages } \\
\text { Stand }\end{array}$ & $\begin{array}{l}\text { Enablers, inhibitors, or no } \\
\text { interlinkages stand as } \\
\text { actions have no evidence of } \\
\text { impact. }\end{array}$ & Actions do not impact Target \\
\hline
\end{tabular}

The two-step mapping methodology was applied to the case of Kibera and geographically centred on the informal settlement. However, we could not ignore the overall supply chain involved in the delivery of energy access. Thus, we mapped any interlinkage between Targets and upstream components of the supply chain that were recognised to impact the provision of energy access in Kibera. Where specific reference to Kibera was lacking, we widened our search, drawing on evidence from the national level and other informal settlements within Kenya, and from the regional level from neighbouring countries in sub-Saharan Africa.

Finally, the list of actions was re-evaluated and improved based on the analysis in Step 2 (see feedback loop in Figure 5). 


\section{References}

1. United Nations Department of Economic and Social Affairs. World Urbanization Prospects: The 2018 Revision (ST/ESA/SER.A/420). (2019).

2. Ritchie, H. \& Roser, M. Urbanization. Our World In Data (2018).

3. United Nations Statistics Division, United Nations Department of Economic and Social Affairs \& United Nations. Millennium Development Goals Indicators. Millennium Development Goals Indicators. The official United Nations site for MDG Indicators http://mdgs.un.org/unsd/mdg/default.aspx (2015).

4. Castán Broto, V. et al. A research agenda for a people-centred approach to energy access in the urbanizing global south. Nat. Energy2, 776-779 (2017).

5. Singh, R., Wang, X., Mendoza, J. C. \& Ackom, E. K. Electricity (in)accessibility to the urban poor in developing countries. WIREs Energy Environ.4, 339-353 (2015).

6. Pelz, S., Pachauri, S. \& Groh, S. A critical review of modern approaches for multidimensional energy poverty measurement. WIREs Energy Environ.7, (2018).

7. Degert, I., Parikh, P. \& Kabir, R. Sustainability assessment of a slum upgrading intervention in Bangladesh. Cities56, 63-73 (2016).

8. Castán Broto, V., Baptista, I., Kirshner, J., Smith, S. \& Neves Alves, S. Energy justice and sustainability transitions in Mozambique. Appl. Energy228, 645-655 (2018).

9. Runsten, S., Fuso Nerini, F. \& Tait, L. Energy provision in South African informal urban Settlements - A multi-criteria sustainability analysis. Energy Strategy Rev.19, 76-84 (2018).

10. Franco, A., Shaker, M., Kalubi, D. \& Hostettler, S. A review of sustainable energy access and technologies for healthcare facilities in the Global South. Sustain. Energy Technol. Assess.22, 92-105 (2017).

11. Brosemer, K. et al. The energy crises revealed by COVID: Intersections of Indigeneity, inequity, and health. Energy Res. Soc. Sci.68, 101661 (2020).

12. Castán Broto, V. \& Kirshner, J. Energy access is needed to maintain health during pandemics. Nat. Energy 5, 419-421 (2020).

13. Cotton, M. D., Kirshner, J. D. \& Salite, D. L. J. The political economy of electricity access: Lessons from Mozambique. Research Report. Oxford Policy Management, Oxford. http://eprints.whiterose.ac.uk/152668/ (2019).

14. United Nations. Transforming our world: the 2030 Agenda for Sustainable Development. A/RES/70/1 (2015).

15. Fuldauer, L. I., Ives, M. C., Adshead, D., Thacker, S. \& Hall, J. W. Participatory planning of the future of waste management in small island developing states to deliver on the Sustainable Development Goals. J. Clean. Prod.223, 147-162 (2019).

16. Fuso Nerini, F. et al. Mapping synergies and trade-offs between energy and the Sustainable Development Goals. Nat. Energy3, 10-15 (2018).

17. Vinuesa, R. et al. The role of artificial intelligence in achieving the Sustainable Development Goals. Nat. Commun.11, 1-10 (2020). 
18. Castor, J., Bacha, K. \& Fuso Nerini, F. SDGs in action: A novel framework for assessing energy projects against the sustainable development goals. Energy Res. Soc. Sci.68, 101556 (2020).

19. Fuso Nerini, F. et al. Connecting climate action with other Sustainable Development Goals. Nat. Sustain.2, 674-680 (2019).

20. Adshead, D., Thacker, S., Fuldauer, L. I. \& Hall, J. W. Delivering on the Sustainable Development Goals through long-term infrastructure planning. Glob. Environ. Change59, 101975 (2019).

21. Keane, F. Kenya's poor at each other's throats. http://news.bbc.co.uk/2/hi/africa/7205762.stm (2008).

22. Desgroppes, A. \& Taupin, S. Kibera: The Biggest Slum in Africa? Cah. D’Afrique Est East Afr. Rev.44, 2333 (2011).

23. Balaton-Chrimes, S. Recognition, coloniality and international development: a case study of the Nubians and the Kenya Slum Upgrading Project. Postcolonial Stud.20, 51-67 (2017).

24. Bird, J., Montebruno, P. \& Regan, T. Life in a slum: understanding living conditions in Nairobi's slums across time and space. Oxf. Rev. Econ. Policy33, 496-520 (2017).

25. Cronin, V. \& Guthrie, P. Alternative approaches to slum upgrading in Kibera, Nairobi. Proc. Inst. Civ. Eng. Urban Des. Plan.164, 129-139 (2011).

26. United Nations. SDG 11 Indicators: Make cities and human settlements inclusive, safe, resilient and sustainable. SDG Indicators https://unstats.un.org/sdgs/report/2019/goal-11/ (2020).

27. GNESD. Country report (Kenya). Energy poverty in developing countries' urban poor communities: assessments and recommendations. Urban and Peri-urban energy access III.Global Network on Energy for Sustainable Development by The Energy, Environment and Development Network for Africa (AFREPREN/FWD) (2014).

28. United Nations. SDG 7 Affordable and Clean Energy. SDG Goals https://unstats.un.org/sdgs/report/2019/goal-07/ (2020).

29. Government of Kenya. The Petroleum (Liquified Petroleum Gas) Regulations, 2019. (2019).

30. Government of Kenya. Kenya Action Agenda. https://www.se4all-africa.org/seforall-in-africa/countryactions/action-agenda/ (2015).

31. Hussein, M. A. \& Filho, W. L. Analysis of energy as a precondition for improvement of living conditions and poverty reduction in sub-Saharan Africa. Sci. Res. Essays7, 2656-2666 (2012).

32. United Nations. About the Sustainable Development Goals. United Nations Sustainable Development https://www.un.org/sustainabledevelopment/sustainable-development-goals/ (2020).

33. Karekezi, S., Kimani, J. \& Onguru, O. Energy access among the urban poor in Kenya. Energy Sustain. Dev.12, 38-48 (2008).

34. Gan, M. \& Van Leeuwen, R. Sustainable Development Goals Contribution of LPG. https://www.wlpga.org/publication/sustainable-development-goals-contributions-of-lpg/ (2019).

35. Lambe, F. \& Senyagwa, J. Identifying behavioural drivers of cookstove use: a household study in Kibera, Nairobi. Stockholm Environment Institute (2015).

36. Fuso Nerini, F., Ray, C. \& Boulkaid, Y. The cost of cooking a meal. The case of Nyeri County, Kenya. Environ. Res. Lett.12, 065007 (2017). 
37. ENERGIA. Gender in the transition to energy for all: from evidence to inclusive policies. ENERGIA the International Network on Gender and Susatinable Energy (2019).

38. de Bercegol, R. \& Monstadt, J. The Kenya Slum Electrification Program. Local politics of electricity networks in Kibera. Energy Res. Soc. Sci.41, 249-258 (2018).

39. Puzzolo, E. et al. Supply Considerations for Scaling Up Clean Cooking Fuels for Household Energy in Low- and Middle-Income Countries. GeoHealth3, 370-390 (2019).

40. van den Berg, I. C. Kenya's Strategy to Make Liquefied Petroleum Gas the Nation's Primary Cooking Fuel. https://openknowledge.worldbank.org/handle/10986/30391 (2018).

41. Kojima, M. The Role of Liquefied Petroleum Gas in Reducing Energy Poverty. http://siteresources.worldbank.org/INTOGMC/Resources/LPGReportWeb-Masami.pdf (2011).

42. Farhar, B. C., Osnes, B. \& Lowry, E. A. Energy and Gender. in Energy Poverty: Global Challenges and Local Solutions (eds. Halff, A., Sovacool, B. K. \& Rozhon, J.) (Oxford University Press, 2014).

43. GNESD. Assessment of selected Outcomes of the Global Network on Energy for Sustainable Development (GNESD). (2016).

44. Singh, R., Wang, X., Ackom, E. K. \& Reyes, J. C. M. Energy access realities in urban poor communities of developing countries: assessments and recommendations. (2015).

45. Haselip, J. A., Larsen, T. H., Ackom, E. K., Mackenzie, G. A. \& Christensen, J. M. Reflections on experience with the global network on energy for sustainable development as a South-South global knowledge network. Energy Sustain. Dev.36, 37-43 (2017).

46. Government of Kenya. National Energy Policy 2018.

https://kplc.co.ke/img/full/BL4PdOqKtxFT_National\%20Energy\%20Policy\%200ctober\%20\%202018.pdf (2018).

47. Government of Kenya. Kenya Vision 2030. http://vision2030.go.ke/about-vision-2030/ (2007).

48. Nilsson, M. et al. Mapping interactions between the sustainable development goals: lessons learned and ways forward. Sustain. Sci.13, 1489-1503 (2018).

\section{Declarations}

\section{Authors Contributions}

E.C. and H.L. designed the study with the supervision of F.F.N. E.C. and H.L. wrote the initial draft of the paper, with intellectual input from F.F.N and E.A. All authors contributed to the revision and restructuring of later versions of the paper.

\section{Competing interests}

The authors declare no competing financial interests.

\section{Supplementary information}

Full results of step 1 and Step 2 mapping as summarised in Figure 3 and 4 . 
Figures

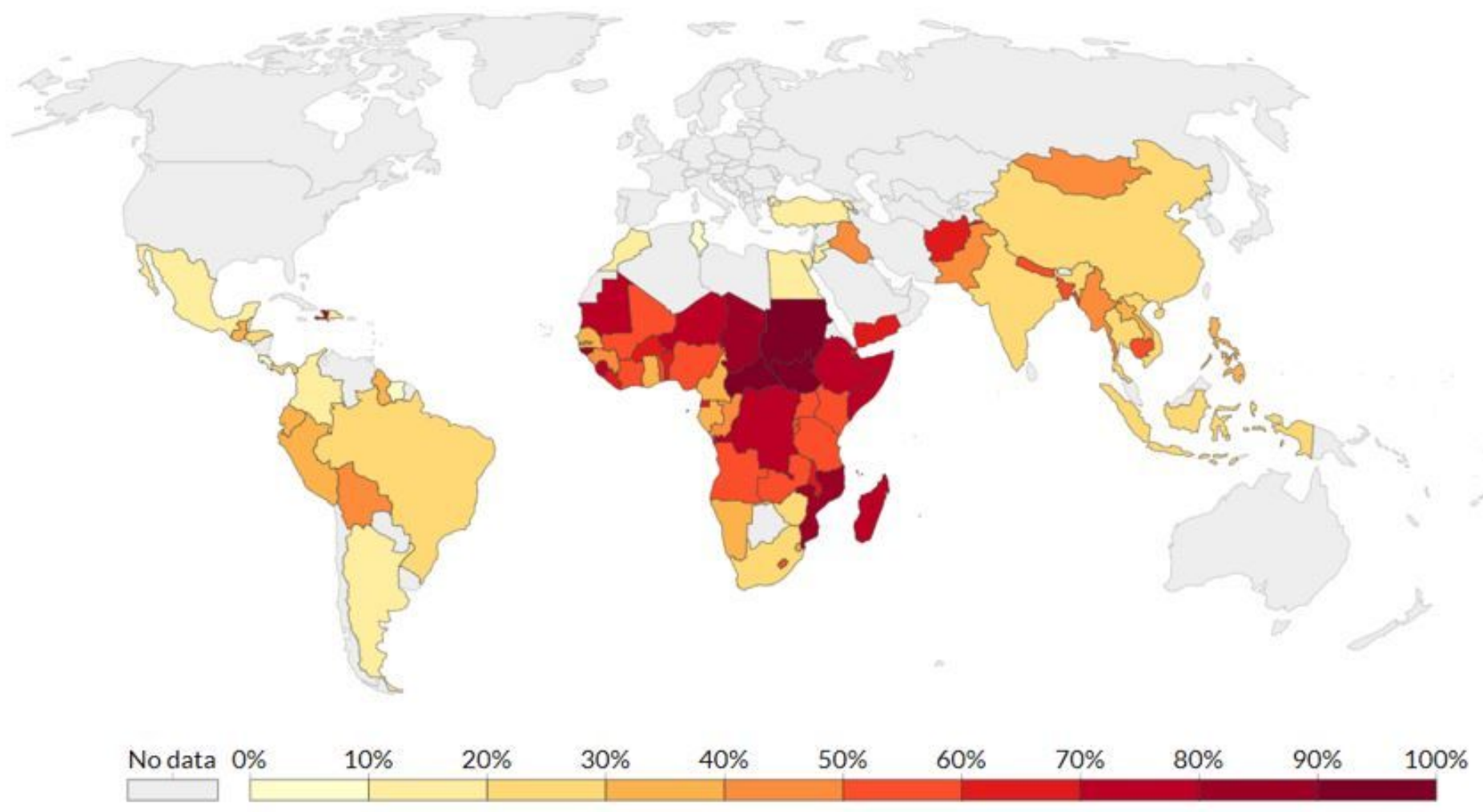

Figure 1

Share of urban population living in slums and informal settlements in 20143. Note: The designations employed and the presentation of the material on this map do not imply the expression of any opinion whatsoever on the part of Research Square concerning the legal status of any country, territory, city or area or of its authorities, or concerning the delimitation of its frontiers or boundaries. This map has been provided by the authors. 


\section{KENYA}

\section{NAIROBI

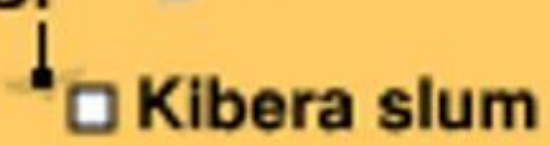

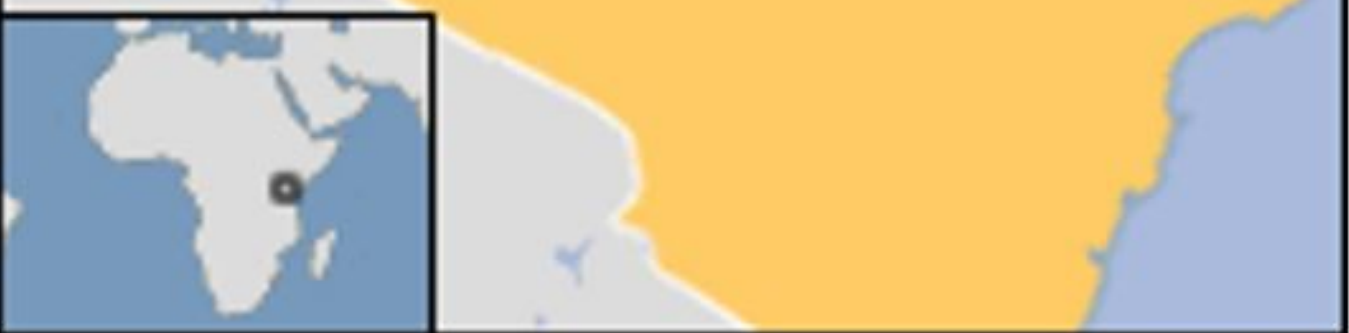

Figure 2

Location of Kibera in Kenya on the continent of Africa 21 

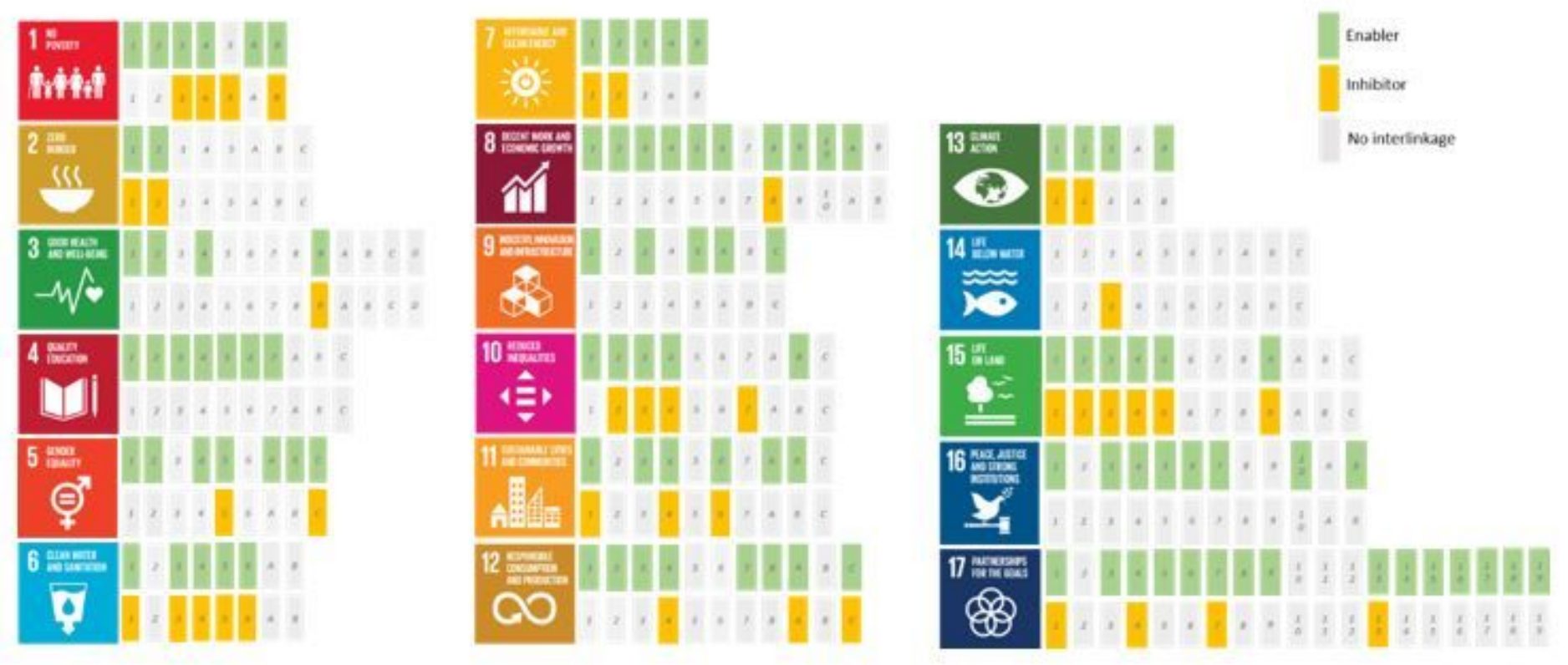

LIQUIFIED PETROLEUM GAS

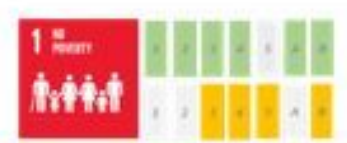

$2=$

III

$-46$

Di

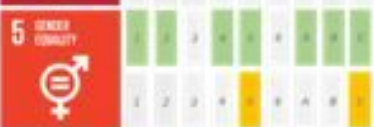

6

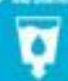

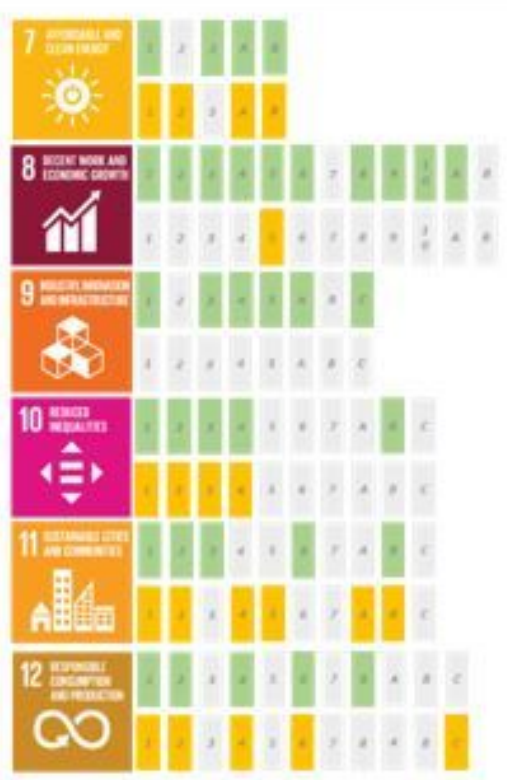

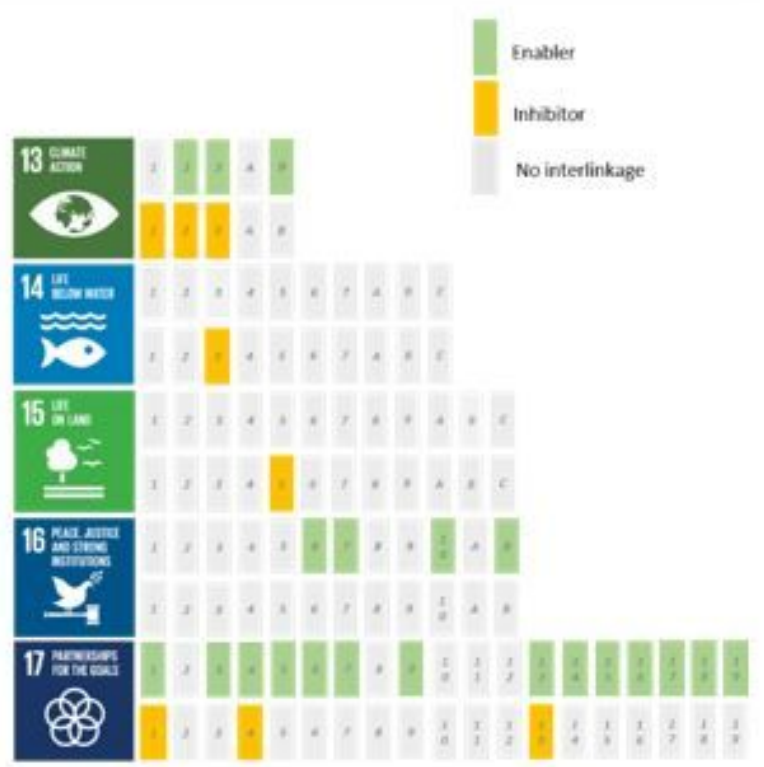

\section{Figure 3}

Detailed assessment of the provision of electricity and LPG access on the SDGs. Evidence of interlinkage that promoted either energy access or Target was marked as an enabler, whilst those that prohibited energy access or Target were marked as an inhibitor from SDGs. In the absence of evidence, no interlinkages were marked, meaning only the absence of published evidence, not necessarily absence of impact. Full results can be found in Supplementary Material. 


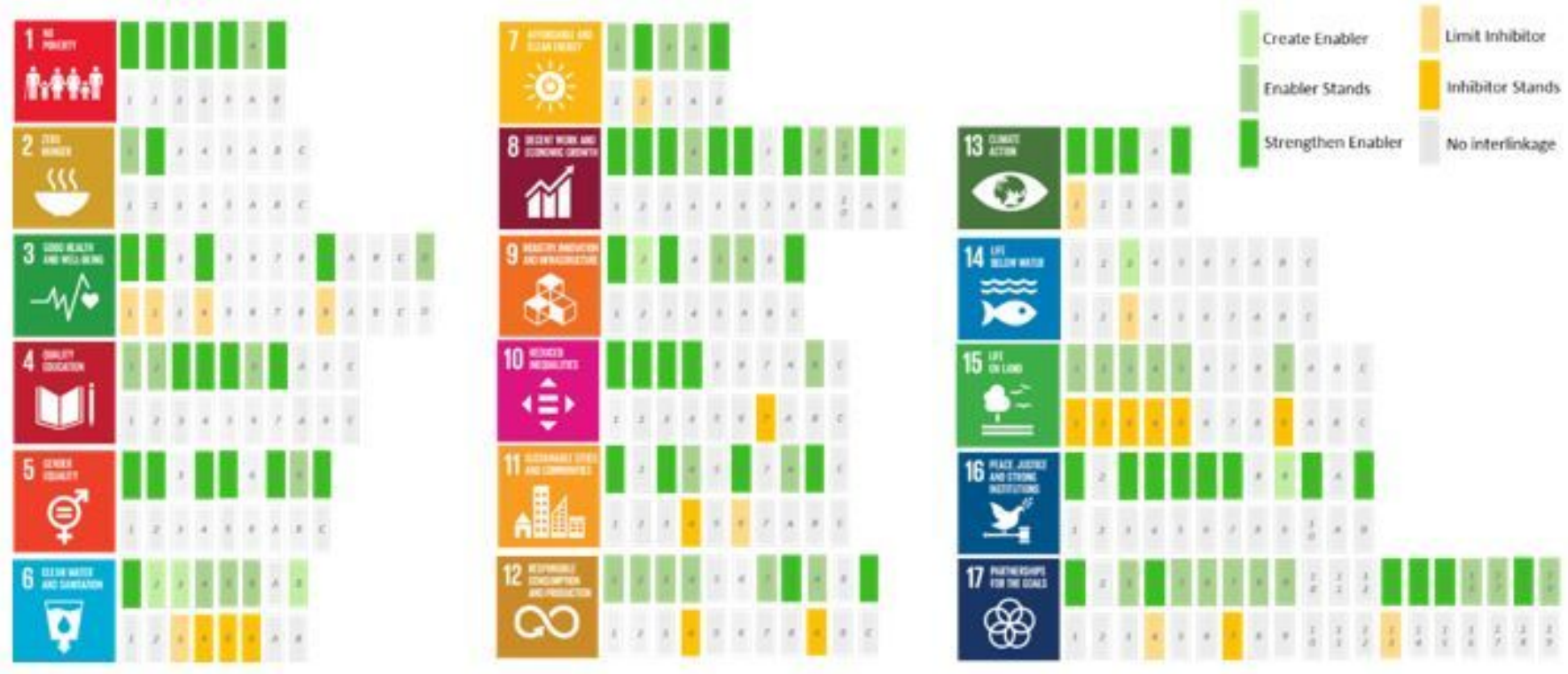

ULUIFIED PETROLEUM GAS
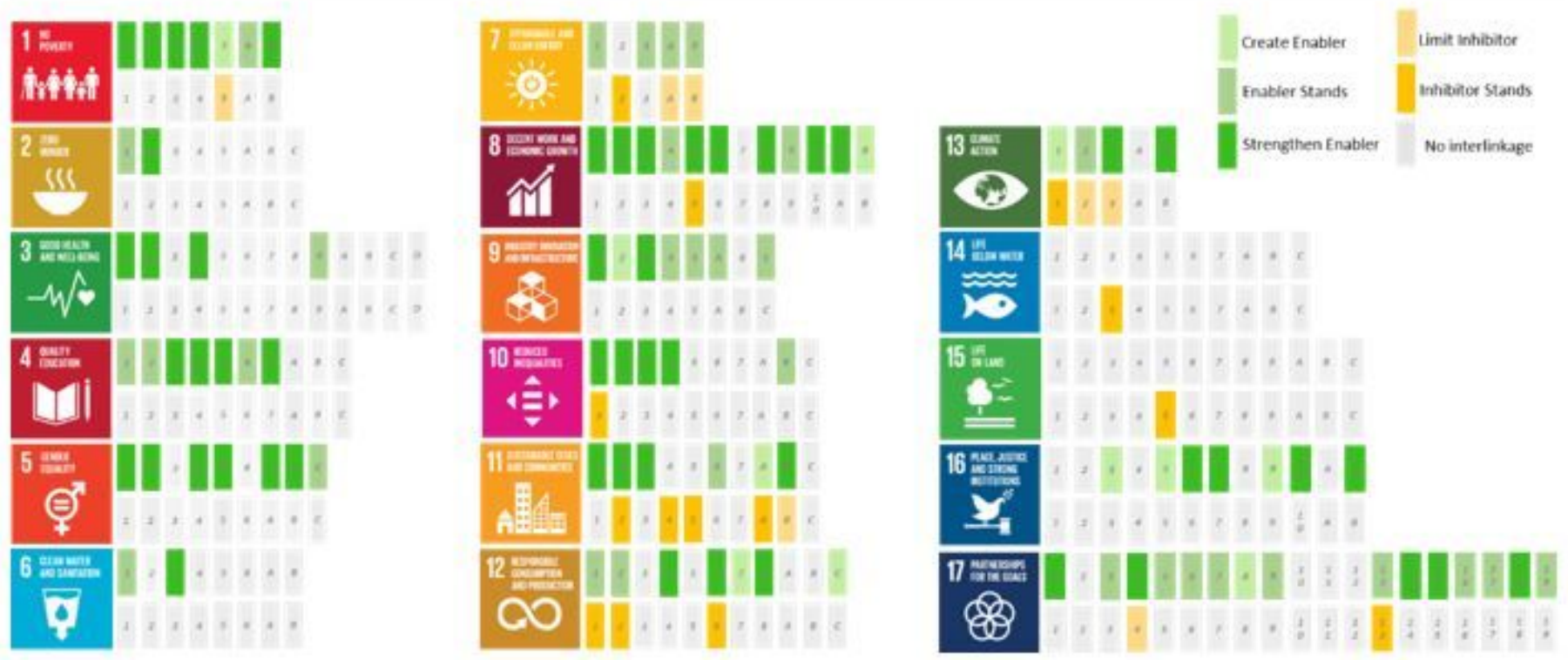

\section{Figure 4}

Detailed assessment of the impact of interventions to promote electricity (top) and LPG (bottom) access on the SDGs. Evidence of impact of interventions on Target was classified as follows: i) New enabler (achievement of Target created by intervention); ii) Strengthened enabler (achievement of Target improved by interventions); iii) Limited inhibitor (barrier(s) to achievement of Target lessened by intervention); iv) Overcame inhibitor (barrier(s) to achievement of Target removed by intervention). In the absence of evidence, no impacts of interventions were marked, meaning only the absence of published evidence, not necessarily absence of impact. Compared to previous mapping (Figure 3 ) actions to promote electricity access strengthen 62 enablers, create a further 7 enablers, overcome 17 inhibitors and limit 11 . Actions to promote LPG access strengthened 52 enablers and created a further 11, overcoming 17 inhibitors and limiting 7. Full results can be found in Supplementary Material. 


\section{Supplementary Files}

This is a list of supplementary files associated with this preprint. Click to download.

- SupplementaryinformationMappingofSustainableDevelopmentGoalsandEnergyAccessinKibera.pdf

- SupplementaryinformationMappingofSustainableDevelopmentGoalsandEnergy AccessinKibera.xIsx

- SupplementaryinformationMappingofSustainableDevelopmentGoalsandEnergyAccessinKibera.pdf 